\title{
Dinamika Peran Sosial Politik Ulama dan Jawara di Pandeglang Banten
}

\author{
${ }^{1}$ ASEP MUSLIM, ${ }^{2}$ LALA M. KOLOPAKING, \\ ${ }^{3}$ ARYA H. DHARMAWAN, ${ }^{4}$ ENDRIATMO SOETARTO \\ 1,2,3,4 Program Studi Sosiologi Pedesaan, Institut Pertanian Bogor (IPB) \\ email: asep_muslim_sy@yahoo.com
}

\begin{abstract}
The focus on this article is to examine the social and political roles of ulama and jawara in Pandeglang (Banten). But recently, there is a trend that there is a decrease in ulama's political roles in one side, and a highly increase in political roles that are played by jawara in the other side. Though in the local political constellation jawara dominate ulama, but in social power aspect ulama is still the most powerful actor and still dominate jawara. To explore this fact, researcher will analyze it by power relation approaches that indicate there are a special kind of patron-client relation between ulama and jawara. In this research, descriptive qualitative is chosen as the research method with a case study as the research approach. Some of ulama, jawara, the elders, santri and the common people (the grassroots) are chosen as the informant by the key person technique. Research found a traditional Bantenese patron-client relation between ulama and jawara that influence the construction of their power relation and the local social and political constellation.
\end{abstract}

Keywords: ulama, jawara, social and political roles, social and political constellation, power relation

\begin{abstract}
Abstrak. Fokus dalam tulisan ini adalah mengkaji peran sosial-politik ulama dan jawara di Pandeglang (Banten). Saat ini, terdapat kecenderungan adanya penurunan dalam peran politik ulama di satu sisi, dan peningkatan yang sangat tinggi dalam peran politik yang dimainkan jawara di sisi lain. Meskipun dalam konstelasi politik lokal jawara mendominasi ulama, tetapi dari sisi aspek kekuasaan sosial ulama masih merupakan aktor yang paling berkuasa dan masih mendominasi jawara. Untuk mengeksplorasi fakta ini, peneliti akan menganalisisnya melalui pendekatan relasi kekuasaan yang mengindikasikan terdapat suatu jenis relasi patron-klien khas antara ulama dan jawara. Dalam penelitian ini, deskriptif kualitatif dipilih sebagai metode penelitian dengan studi kasus sebagai pendekatannya. Beberapa ulama, jawara, sesepuh (tokoh masyarakat), santri dan masyarakat biasa dipilih sebagai informannya melalui teknik key person berdasarkan strategi purposive sampling. Penelitian menemukan suatu relasi patron-klien khas Banten antara ulama dan jawara yang memengaruhi konstruksi relasi kekuasaannya dan konstelasi sosial politik lokal.
\end{abstract}

Kata kunci: ulama, jawara, peranan sosial-politik, konstelasi sosial politik, relasi kekuasaan

\section{Pendahuluan}

Dinamika hubungan ulama dan jawara menjadi sangat menarik untuk dikaji karena ternyata perkembangan kebijakan politik menjadi faktor determinan terhadap relasi tersebut, sehingga dalam hal ini tidak hanya faktor sosial-kultural yang memberikan pengaruhnya. Oleh karenanya, dalam melakukan kajian tentang ulama dan atau jawara tidak hanya bisa ditinjau dari dimensi sosial-kultural semata, namun justru faktor kebijakan politiklah yang banyak memengaruhinya.

Fakta ini, misalnya dapat ditelusuri dari beberapa kesimpulan yang diambil dari penelitian Hamid (2010) tentang proses keterpinggiran peran politik ulama di satu sisi dan dominasi kekuasaan jawara pada sisi lainnya, sedangkan Bandiyah (2010) dalam penyelitiannya menyebutkan adanya dua faktor yang mendukung terhadap eksistensi jawara dalam politik lokal yaitu faktor daya upaya aktor dan faktor kesempatan untuk

Received: 28 Agustus 2015, Revision: 22 November 2015, Accepted: 18 Desember 2015

Print ISSN: 0215-8175; Online ISSN: 2303-2499. Copyright@2015. Published by Pusat Penerbitan Universitas (P2U) LPPM Unisba Terakreditasi SK Kemendikbud, No.040/P/2014, berlaku 18-02-2014 s.d 18-02-2019 
berubah dan Pribadi (2011) dalam kesimpulan mengemukakan bahwa meskipun jawara menjadi semacam raja kecil di politik lokal Banten, namun relasinya dengan ulama masih menandakan kepatuhannya kepada tokoh agama tersebut yang berarti ikatan patronklien di antara keduanya masih terjalin.

Kuat dan lemahnya relasi kekuasaan ulama dan jawara banyak dikaitkan dengan terjadinya pergeseran peran sosial dari kedua tokoh informal ini, sehingga kesan pembalikkan peran yang selama ini nampak dalam konstelasi politik lokal Banten dimana jawara cenderung lebih mendominasi terungkap dalam penelitian Suhaedi (2003) yang menyimpulkan bahwa,

Adanya kedudukan, peran dan jaringan membuat kiai dan jawara menciptakan kultur tersendiri yang agak berbeda dengan kultur dominan masyarakat Banten, sehingga kiai dan jawara tidak hanya menggambarkan suatu sosok tetapi juga telah menjadi kelompok yang memiliki nilai, norma dan pandangan hidup yang khas, inilah yang disebut dengan sub kultur kiai dan jawara.

Selain beberapa penelitian tersebut, hasil penelitian Karomani (2005) menyatakan bahwa,

persepsi (positif maupun negatif) ulama terhadap jawara dipengaruhi oleh faktor kedekatan, kesamaan kepercayaan, nilai, pandangan dunia, pemahaman agama, dan prasangka, serta pengalaman hidup ulama dengan sosok jawara.

Meskipun penampilan jawara secara politik relatif mendominasi, ternyata tidak mengubah kekuasaan sosial ulama yang lebih powerful dibandingkan dengan jawara sebagaimana temuan penelitian Pribadi (2011), faktor ini terjadi karena masih terjalinnya relasi patron-klien diantara keduanya. Hal ini mengindikasikan bahwa terdapat perbedaan kondisi antara peran sosial-politik keduanya dengan struktur kekuasaan yang ada. Inilah pertautan kondisi yang sangat unik antara dua kekuatan penguasa religi dan aktor tradisi sebagai karakter dasar dari masyarakat pedesaan Banten dan Pandeglang khususnya. Dengan memahami latar belakang ini, tujuan penelitian dilakukan untuk menganalisis peran-peran sosial politik ulama dan jawara yang dipengaruhi oleh relasi kekuasaan keduanya..

Artikel ini menggunakan metode kualitatif dengan pendekatan analisis dekriptif. Untuk memaknai secara mendalam peran sosial-politik ulama dan jawara, maka studi kasus dipilih sebagai metode penelitiannya. Sementara itu, untuk memahami studi kasus sebagai strategi penelitiannya ini, maka terdapat tiga kondisi batasan yang menjadi penekanannya yaitu menyelidiki fenomena dimana konteks kehidupan nyata, bilamana; batas-batas antara fenomena dan konteks tidak tampak dengan tegas; dan di mana: multi sumber bukti dimanfaatkan (Yin, 1996: 18; Bungin, 2010: 20).

Dalam penelitian kualitatif ini, signifikansi pengumpulan data bukanlah ditekankan kepada pengukurannya, tetapi data yang dapat menjelaskan fenomena penelitian. Untuk itu pengambilan data primer dalam penelitian ini dilakukan melalui metode utama pengumpulan data yaitu teknik wawancara mendalam (in depth interview) dan pengamatan terlibat (participatory observation) yang peneliti anggap paling ampuh untuk menjelaskan maksud dari tujuan penelitian. Sementara, data sekunder diperoleh melalui teknik studi literatur. Sebagai data utama dalam penelitian ini adalah data primer tersebut, adapun datadata sekunder digunakan sebagai data yang sifatnya melengkapi dan mengkonfirmasi data primer.

Adapun teknik pengambilan informan dilakukan secara purposive melalui teknik key person yaitu para informan dengan karakter spesifik yang dianggap menguasai permasalahan, terutama informan kunci ulama dan jawara. Informan penelitian yang diambil mewakili unsur tokoh ulama, tokoh jawara, santri, tokoh masyarakat desa dan masyarakat biasa (akar rumput).

\section{Kerangka Teoretis}

Pada prinsipnya, konsep kekuasaan mendorong berlangsungnya proses zerosum yang dapat dianalogikan bahwa satu pihak akan memperoleh keuntungan dan pihak lain akan menanggung kerugian. Karena pendekatan zero-sum inilah yang menyebabkan kekuasaan tidak terelakkan dari situasi konfliktual dengan logika pemikirannya adalah bahwa satu sama lain dari kelas yang berhadap-hadapan akan berupaya memertahankan atau meraih kekuasaannya. Dengan demikian, sebenarnya relasi kekuasaan cukup tepat untuk dikaji dari pendekatan Marxian yang memandang bahwa dalam relasi kekuasaan selalu ada kelas yang dominan (superordinat) dan kelas yang tersubordinasi, dan oleh karenanya sangat memungkinkan adanya gerakan perlawanan sebagai tipikal Marxian.

Dalam memahami relasi kekuasaan 
Marxian ini dapat ditelusuri dari empat pijakan pendekatannya (Jessop, 2006:7), yaitu:

pertama, relasi kekuasaan sebagai manifestasi dari mode atau konfigurasi khusus dari dominasi kelas daripada sebagai fenomena hubungan interpersonal murni. Kedua, relasi kekuasaan sangat memerhatikan hubungan antara ekonomi, politik dan dominasi ideologi kelas. Ketiga, relasi kekuasaan memerhatikan keterbatasan-keterbatasan yang melekat dalam banyak eksekusi kekuasaan yang berakar dalam suatu kelas atau bentuk dominasi kelas lainnya dan mencoba untuk menjelaskan ini dalam kontradiksi dan antagonisme struktural. Keempat, Marxian mengarahkan pada strategi dan taktik untuk mereproduksi, mempertahankan atau menggulingkan dominasi kelas.

Adanya kelas dominan dalam pendekatan Marxian ini memunculkan konsep dominasi dengan persetujuan akibat dari terlalu kuatnya kelas dominan dan ketidakmampuan kelas subordinat untuk "melawan" kekuasaan kelas dominan tersebut. Untuk mengelaborasi kondisi semacam ini, Gramsci mengintrodusirnya sebagai kondisi hegemonik.

Kondisi hegemoni masih sangat relevan dalam analisis politik lokal terutama pasca era otonomi daerah lahir. Banyak kelompok mencoba tampil dalam arena politik lokal dimana pada skenario akhirnya terbentuklah pola hegemoni baru dalam konstelasi politik di tingkat lokal.

Hal yang sama terjadi dalam arena politik Banten yang melahirkan dinasti politik jawara - istilah yang sering disitir oleh banyak kalangan, awam maupun para ahli analis politik. Fakta ini tidak terbantahkan sebagai realitas konkret konstelasi politik lokal Banten di masa kini, dimana jawara mendominasi hampir seluruh sektor politik lokal. Dalam bagian lain, meskipun secara kelembagaan negara (baca: pemerintahan daerah) ulama terhegemoni oleh kekuatan jawara, tetapi pengaruh sosialnya sebenarnya masih jauh lebih mendominasi dibandingkan dengan jawara. Sementara itu, relasi personal yang terbentuk diantara kedua kelompok tersebut relatif masih berlangsung secara patronklien yang menempatkan posisi ulama lebih superior dibandingkan dengan jawara, lihat dalam Pribadi (2011).

Oleh karena itu, selain gambaran relasi kekuasaan yang bersifat hegemonik, hubungan perikatan berbasis patrimonial juga sangat kental dalam sistem sosial Banten. Inilah yang menjadikan alasan untuk menjelaskan relasi kekuasaan ulama dan jawara dalam kerangka teori patron-klien Scott. Teori patron-klien Scott menggambarkan ikatan antara pelindung (patron) dan klien sebagai suatu bentuk asuransi sosial yang terdapat dimana-mana di kalangan petani Asia Tenggara yang dalam hal lainnya berkaitan dengan jarak sosial dan seringkali moral, teristimewa apabila sang pelindung bukan warga desa. Apakah ia seorang tuan tanah, seorang pejabat kecil atau pedagang. Seorang patron menurut definisinya adalah orang berada dalam posisi untuk membantu klienkliennya (Scott, 1994: 41).

\begin{abstract}
Hubungan patron-klien merupakan kasus khusus hubungan dua orang yang sebagian besar melibatkan hubungan instrumental, dimana seseorang dengan status sosial ekonomi lebih tinggi (patron) menggunakan pengaruh dan sumber daya untuk memberikan perlindungan dan atau keuntungan kepada seseorang dengan status lebih rendah yang pada gilirannya membalas pemberian dengan dukungan dan bantuan, termasuk jasa pribadi kepada patron (Scott, 1994: 7).
\end{abstract}

Teori patron-klien Scott adalah gambaran ketidakberdayaan klien terhadap kuasa patronase sehingga hubungan tersebut menjadi "langgeng" karena ketidakmampuan klien untuk mengubah kondisi yang ada yang kemudian justru membentuk hubungan moral.

Dalam kaitannya dengan hubungan antara patron-klien dan teori pertukaran, berdasarkan paparan di atas, terdapat satu hal penting yang dapat digarisbawahi, yaitu bahwa pada prinsipnya dalam pola hubungan patronklien terdapat unsur pertukaran. Hubungan pertukaran sangat nyata berlangsung antara patron yang memberikan perlindungan dan klien yang memberikan dukungan, sehingga dapat disimpulkan bahwa pola hubungan patron-klien dapat dimasukkan ke dalam hubungan pertukaran yang lebih luas, yaitu teori pertukaran.

Scott memang tidak secara langsung memasukkan hubungan patron-klien ke dalam teori pertukaran. Namun demikian, jika memperhatikan uraian-uraian teorinya, maka akan terlihat di dalamnya unsur pertukaran yang merupakan bagian terpenting dari pola hubungan patronase. Menurut Scott, hubungan patron-klien berawal dari adanya pemberian barang atau jasa dalam berbagai bentuk yang sangat berguna atau diperlukan oleh salah satu pihak, bagi pihak yang menerima barang atau jasa tersebut berkewajiban untuk membalas pemberian tersebut (Scott, 1992: 91).

Berdasarkan penjelasan di atas, dapat ditarik pertautan antara hubungan patronklien dengan teori pertukaran, meskipun 
pertukaran yang berlangsung antara patron dan klien terjadi dalam pola yang tidak seimbang (ketergantungan klien terhadap patron), sehingga sangatlah tepat untuk mempersandingkan hubungan patron-klien ini dalam teori pertukaran ketergantungan (exchange dependency theory).

Dengan memaknai bahwa relasi patronklien sebagai bentuk pertukaran yang tidak seimbang, fenomena ini menurut peneliti dapat pula ditemukan dalam hubungan antara ulama sebagai patron dan jawara sebagai klien dengan pemikiran dasar bahwa masing-masing mengambil keuntungan dari hubungan yang terjadi diantara keduanya.

\section{Ulama dan Jawara dalam Konsep Masyarakat Pandeglang}

Sebagai sebuah konstruksi sosial, konsep ulama dan jawara tentunya berbeda untuk masing-masing masyarakatnya, termasuk di Banten. Konsep ulama dan jawara bagi masyarakat Pandeglang terjadi karena pengaruh kultur agraris-tradisional yang mewarnai kehidupan mayoritas masyarakat Pandeglang memberikan pemaknaan dan nilai-nilai penghargaan terhadap ulama dan jawara yang lebih tinggi, terutama jika dibandingkan dengan wilayah utara Banten. Ciri tradisional-agraris masyarakat Pandeglang ini berkontribusi besar terhadap terpeliharanya nilai-nilai kearifan lokal dibandingkan dengan wilayah-wilayah Banten lainnya yang lebih modernis dan metropolis yang sandaran kehidupannya berpijak kepada nilai-nilai utilitarian. Untuk itulah pemahaman ulama bagi masyarakat Pandeglang memiliki makna yang jauh lebih mendalam daripada sekadar sekelompok orang yang dianggap memiliki wawasan keilmuan ajaran Islam saja.

Latar historis hubungan ulama dan jawara dapat dijadikan dasar untuk memahami lebih jauh tentang konsep ulama dan jawara bagi masyarakat Pandeglang. Dalam hubungan tersebut sebagaimana dijelaskan oleh Tihami (1992: 99-100),

Jawara adalah murid atau santri-nya kiai, dan jawara dibentuk oleh kiai dalam rangka mengawal gerakan perjuangan kebangsaan sehingga nilai-nilai patriotisme sangat melekat dalam tubuh seorang jawara pada masa itu.

Dari hubungan tersebut dapat diambil makna pertama: pada dasarnya kyai pastinya menguasai keilmuan kajawaraan, karena kemampuan supra natural yang dipunyai oleh jawara berasal dari pemberian ulama. Dalam hal inilah masyarakat Pandeglang memercayai bahwa kiai memiliki kemampuan magis seperti tahan senjata tajam, tahan senjata api, memiliki kemampuan menolak teluh (tenung), dan kemampuan-kemampuan supranatural lainnya. Oleh karenanya tidak sedikit orang yang mencari pertolongan kepada kiai dalam urusan-urusan supra natural.

Kemampuan para kiai ini diyakini masyarakat sebagai bagian dari hasil wiridan yang dilakukannya, ia diberikan sejumlah kemampuan supra natural dalam bentuk hizib. Hizib adalah beberapa amalan atau wiridan mengagungkan kuasa Ilahi yang sering dilakukan oleh para kiai, jawara ataupun santri untuk memperoleh kekuatankekuatan supra natural tertentu semisal hizib Bagdad Jaelani, Asror, Rifai, Khoufi, Barqi, Nasor dan Isim Tunggal. Setiap hizib juga mengandung tingkatan-tingkatan tertentu tergantung rangkaian tarekat yang sudah dijalankan. Semakin tinggi tingkatan hizib, maka semakin berat tantangan yang dihadapi untuk lulus dalam tingkatan tersebut). Cara memperoleh kemampuan melalui hizib inilah yang pada akhirnya memilah dua tipikal kiai sebagai kiai kitab atau dalam bahasa lokal disebut sebagai kiai bale rombeng dan kiai hikmah. Kiai hikmah-lah yang dalam hal ini memfokuskan diri melakukan tarekat tertentu untuk memperoleh kemampuan supra natural tersebut, sementara kiai kitab lebih memfokuskan diri pada orientasi dakwah saja.

Kedua, jawara juga memahami keilmuan keagamaan karena pernah menjadi murid kiai. Sebagai seorang mantan santri, jawara setidaknya dibekali ajaran-ajaran ke-islaman yang memagari kehidupannya. Untuk menurunkan sejumlah kemampuan, kiai memedomani jawara dengan serangkaian pertalekan (wawancara dengan Halil). Pertalekan ini semacam perjanjian untuk tidak melakukan tujuh Mim (huruf Hijaiyah yang identik dengan $M$ dalam huruf Latin) yaitu maling (mencuri), maen (judi), madon (main perempuan), madat (candu), mangani (memakan barang haram), mateni (membunuh), dan minum (mabok-mabokan) yang jika dilanggar maka dua risiko yang harus ditanggung oleh jawara yaitu pertama ilmunya akan hilang dan kedua kemungkinan keilmuannya akan menjadi bumerang bagi dirinya sendiri yaitu bisa menjadi gila atau kematian; istilah lokalnya adalah "teu kataekan" (tidak lulus sebagai murid) (hasil wawancara dengan Halil).

Dalam pengamatan peneliti, pada 
masa lalu seorang tokoh jawara atau guru perguruan silat biasanya juga menjadi guru ngaji dengan murid yang cukup banyak. Dalam hal ini, jawara tersebut dipercaya sebagai seseorang yang memiliki kemampuan keagamaan. Dalam rangkaian pengajarannya tersebut, jawara menyertakan pula pemberian materi-materi ilmu bela diri yang biasanya dilakukan setiap malam Jum'at untuk pengisian materi kebathinan dan malam Minggu untuk pembelajaran praktek jurusjurus silat (ulinan).

Ketiga, terkait hubungan jawara sebagai murid dan kiai sebagai guru, maka kedudukan kiai dalam hal ini lebih superior dibandingkan dengan jawara. Bagaimanapun hubungan guru dan murid bagi masyarakat Pandeglang dapat dipandang sebagai hubungan patron-klien. Hal ini dapat menggambarkan ketundukan jawara terhadap kiai. Pola relasi kekuasaan ini kemudian akan memengaruhi hubungan keduanya pada kehidupan sosial-politik lokal (hasil pengamatan penelitian).

Berdasarkan uraian di atas dapat ditarik suatu kesimpulan bahwa terdapat keterkaitan yang sangat erat antara agama dan kajawaraan. Menurut Halil, "moal bisa asup mun teu bisa syahadat jeung teu bisa meuncit congcot" yang artinya tidak mungkin bisa masuk - maksudnya ilmunya diserap jika ia tidak bisa syahadat dan "memotong tumpeng". Syahadat adalah pernyataan keyakinan kebenaran ajaran Nabi Muhamad dan Islam. Sedangkan meuncit congcot atau "memotong tumpeng" adalah makna kias dari orang yang mampu ber-tawasyul membaca silsilah yaitu runtutan do'a yang biasa dilakukan oleh masyarakat Islam pedesaan Banten dan khususnya Pandeglang, sehingga seseorang yang akan belajar ilmu kajawaraan terlebih dahulu ia harus mampu menghafal dan merapalkan silsilah do'a tersebut.

Berdasarkan hasil wawancara dengan tokoh ulama dan santri, ditemukan fakta bahwa jawara dibentuk kiai dalam rangka mengawal gerakan perlawanan terhadap kolonialis Belanda, suatu proses yang sudah diawali sebelumnya sejak masa kesultanan Banten. Hal ini dilakukan dalam rangka menangkal gerakan perlawanan dari golongan elmu hideung. Menurut keyakinan masyarakat Pandeglang yang berkembang di kalangan pesantren salafiyah bahwa pasca ditundukkannya Pucuk Umun yang diyakini masyarakat sebagai pimpinan Baduy sebenarnya masih ada rasa dendam dari kalangan masyarakat Baduy tersebut (golongan elmu hideung), sehingga untuk mengantisipasi gerakan perlawanannya dibentuklah jawara sebagai tameng kekuasaan elmu putih.

Konstruksi konsep jawara di masyarakat Pandeglang menurut peneliti dipengaruhi pula oleh posisi wilayah Pandeglang yang berbatasan dengan wilayah Lebak. Kebijakan pihak kesultanan Banten pada masa lalu menjadikan Pandeglang sebagai tameng pertama terhadap pengaruh anak buah Pucuk Umun (masyarakat Baduy) yang melarikan diri ke wilayah Lebak, sehingga berdasarkan kewilayahannya tersebut dijadikanlah Pandeglang sebagai benteng kesultanan Banten untuk menangkal pengaruh tersebut, sehingga aktivitas ke-islam-an dengan adanya pesantren-pesantren dan masjidmasjid yang ada di Pandeglang jauh lebih semarak dibandingkan dengan kegiatan keIslaman di Lebak pada saat itu.

\section{Ulama dalam Derajat Keilmuannya}

Tingkatan ulama yang dikenal masyarakat Pandeglang terdiri dari wali, abuya, kiai dan ustadz, pada prinsipnya dikonsepsikan berdasarkan derajat keilmuannya. Berdasarkan tingkatan ulama ini, jika diurutkan dari yang paling bawah, dalam kaitannya dengan hubungan guru dan murid maka ustaz pada prinsipnya mendapatkan keilmuan dari kiai, kiai belajar ke abuya dan abuya mendapatkan pengetahuan dari wali. Meskipun dalam beberapa kondisi bisa saja seorang ustadz belajar langsung ke abuya atau ustadz yang menuntut ilmu dari seorang abuya, karena hak menuntut ilmu tidak dibedakan atas statusnya.

Dengan menempatkan wali sebagai derajat tertinggi dalam herarki ulama di Pandeglang, maka abuya pastinya tunduk dan patuh terlebih kedudukan-kedudukan ulama yang ada di bawahnya yaitu para kiai dan ustad. Sementara itu, untuk mengategorisasikan konsep wali akan sulit karena dalam pandangan masyarakat Pandeglang wali akan menyembunyikan identitas kewaliannya.

Berbeda dengan kiai yang justru memiliki peranan yang strategis dalam mengendalikan masyarakat, baik secara sosial maupun politik. Sementara, abuya seperti halnya wali juga cenderung menjaga jarak dengan urusan-urusan keduniaan, abuya hanya "terjun ke arena" jika ia pandang perlu saja. Dalam suatu waktu pada masa Orde Baru, pemerintahan pada saat itu melakukan 
kebijakan untuk menyetop pasokan BBM (Bahan Bakar Minyak) ke wilayah Pandeglang karena aspek politik dimana pada saat itu akan dilakukan kampanye PPP (Partai Persatuan Pembangunan). Kebijakan ini mengakibatkan masyarakat mengalami kesulitan dalam memperoleh BBM, meskipun ada tetapi dengan harga yang cukup tinggi, sehingga pada saat itu kampanye pun terancam gagal dan masyarakat terhimpit dalam kesulitan BBM. Akhirnya, dengan kemampuan supra natural yang dipunyainya, Abuya Dimyati memerintahkan kendaraan-kendaraan untuk diisi air yang berasal dari kolamnya, ternyata kendaraan tersebut dapat dijalankan meski dengan air yang diisi dari kolam tersebut (Hasil wawancara dengan Wahyudin, warga masyarakat sebagai saksi kejadian ini). Kejadian-kejadian yang menjadi folklor lokal ini semakin meninggikan posisi ulama di mata masyarakat Pandeglang.

Sebagaimana disebutkan di atas, dapat dikatakan bahwa diantara hirarki ulama yang ada, dalam kaitannya dengan pengaruh sosial-politiknya kiai memainkan peranan yang paling signifikan. Jika dilihat dari posisi struktur tokoh agama (lihat dalam Gambar 1), posisi kiai berada pada posisi menengah dalam fungsinya menjembatani ke bawah dan ke atas. Dalam pengamatan peneliti, hal ini juga terjadi karena konsentrasi rasio urusan dunia dan agama (akhirat) yang dijalankan oleh kiai yang relatif berimbang, sementara untuk abuya dan wali sebagaimana penjelasan sebelumnya, meskipun memiliki tingkatan keilmuan yang lebih tinggi, namun karena persinggungannya dengan umat (urusan dunia) lebih kecil sehingga pengaruh sosialnya jauh lebih kecil.

Contoh konkret rendahnya ketersing- gungan wali dan abuya dibandingkan dengan kyai dan ustadz adalah dalam pola-pola dakwah yang dilakukannya wali dan abuya sebenarnya hanya memberikan materi-materi dakwah dalam kapasitas massa yang sangat besar, itu pun jarang menyentuh urusanurusan keilmuan, tetapi lebih banyak kepada pola-pola tarekat saja sebagaimana yang dilakukan oleh Abuya Muhtadi, sementara urusan pembelajaran dan dakwah dilakukan oleh kiai, ustadz atau santri senior yang dipercayakannya. Hal inilah yang menjadikan kurang dekatnya hubungan masyarakat dengan abuya. Di sisi lain, sangat sukar untuk bersilaturahmi (bertemu) langsung dengan abuya karena sebagian besar waktunya hanya untuk beribadah (muamalah).

Adanya pemilahan kiai kitab dan kiai hikmah sebenarnya perlu diberikan perhatian yang berbeda ketika memahami rasio urusan kiai karena dalam kondisi dengan dua jenis kiai tersebut terdapat perbedaan yang sangat jauh yaitu urusan keduniaan lebih mendominasi kiai hikmah dibandingkan dengan kiai kitab yang lebih menjaga jarak dengan urusan keduniaan. Apalagi jika harus membandingkannya dengan tipologi kyai politik yang pastinya curahan waktunya akan lebih banyak kepada urusan duniawi (politik) dibandingkan dengan urusan agama. Dalam analisis yang berbeda, Faridl (2005: 175) menyatakan bahwa,

Tipologi politik terwujud dari adanya perbedaan persepsi teologis dengan perilaku sosial politik yang diperankannya, oleh karenanya dalam analisis Faridl ini bahwa adanya kiai politik dan non politik terbentuk diawali pemahaman teologi yang dimilikinya.

Dalam skenario lainnya, tingkatan ulama juga memengaruhi relasi kekuasaan

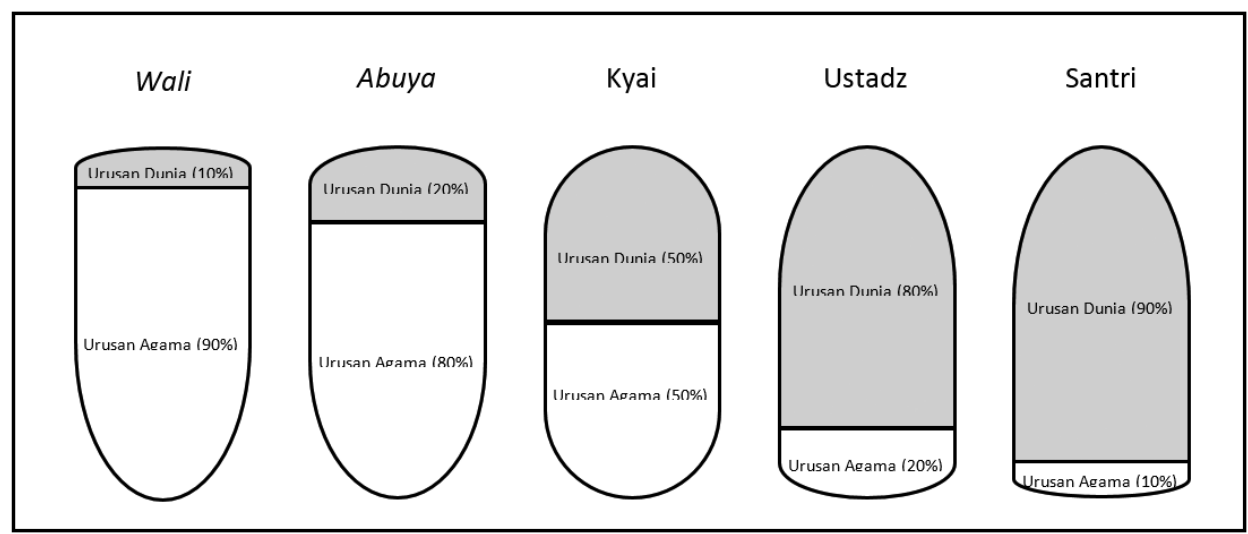

Sumber: pengamatan peneliti

Gambar 1

Perbandingan Urusan Diantara Pelaku Keagamaan di Pandeglang 
di antara sesama ulama dalam level yang sama maupun berbeda. Layaknya hubungan guru dan murid, maka hubungan patronklien adalah ciri khas relasi kekuasaan yang membingkai hubungan diantara unsur-unsur ulama tersebut. Bahkan ketundukan sebagai murid kepada guru yang dibalut oleh nilainilai agama Islam jauh lebih mendalam dibandingkan dengan pola hubungan guru dan murid dalam kehidupan kemasyarakatan umumnya. Nilai-nilai kearifan lokal juga memengaruhi hubungannya secara lebih kuat lagi semisal dengan kepercayaan seperti mun ngamal elmu teu make guru, pasti elmu eta ti setan. Artinya, jika mengamalkan ilmu tanpa pemberian dan bimbingan dari guru tertentu, pasti ilmu itu datangnya dari setan.

Dalam pandangan masyarakat Pandeglang, pemberian barokah sebagai unsur yang paling dicari dalam jalinan hubungan dengan ulama juga menentukan. Untuk itulah proses hubungan dengan ulama tidak semata dalam rangka memperoleh keilmuan agama, tetapi juga dalam hal lain banyak pula yang bertujuan untuk mendapatkan barokah yang diberikan oleh kaum ulama. Keyakinan akan nilai-nilai kearifan lokal berkaitan dengan barokah kiai ini sangat tampak, misalnya jika dikaitkan dengan kepercayaan bahwa "ciduhna kyai, barokah keur santri" yang artinya air ludah kyai sebagai berkah untuk santri. Hal ini mengindikasikan klientelisme yang dibalut hubungan keikhlasan dan barokah di mana karakternya sangat jauh berbeda dengan hubungan patron-klien Scottian yang berbasis pertukaran materi.

Berdasarkan derajat keulamaan dan kajawaraan ini terbentuk struktur kekuasaan masyarakat Banten dalam kaitannya dengan ulama dan jawara. Struktur kekuasaan yang terbentuk menggambarkan tingkatan ulama dan tingkatan kajawaraan yang ada di masyarakat. Dalam hal ini, maka semakin tinggi tingkat keulamaan semakin tinggi pula struktur yang dimilikinya. Gambaran struktur kekuasaan dengan memertimbangan terminologi ulama tersebut dijelaskan dalam Gambar 2.

Tidak selamanya jawara berada pada posisi subordinat terhadap ulama. Dalam

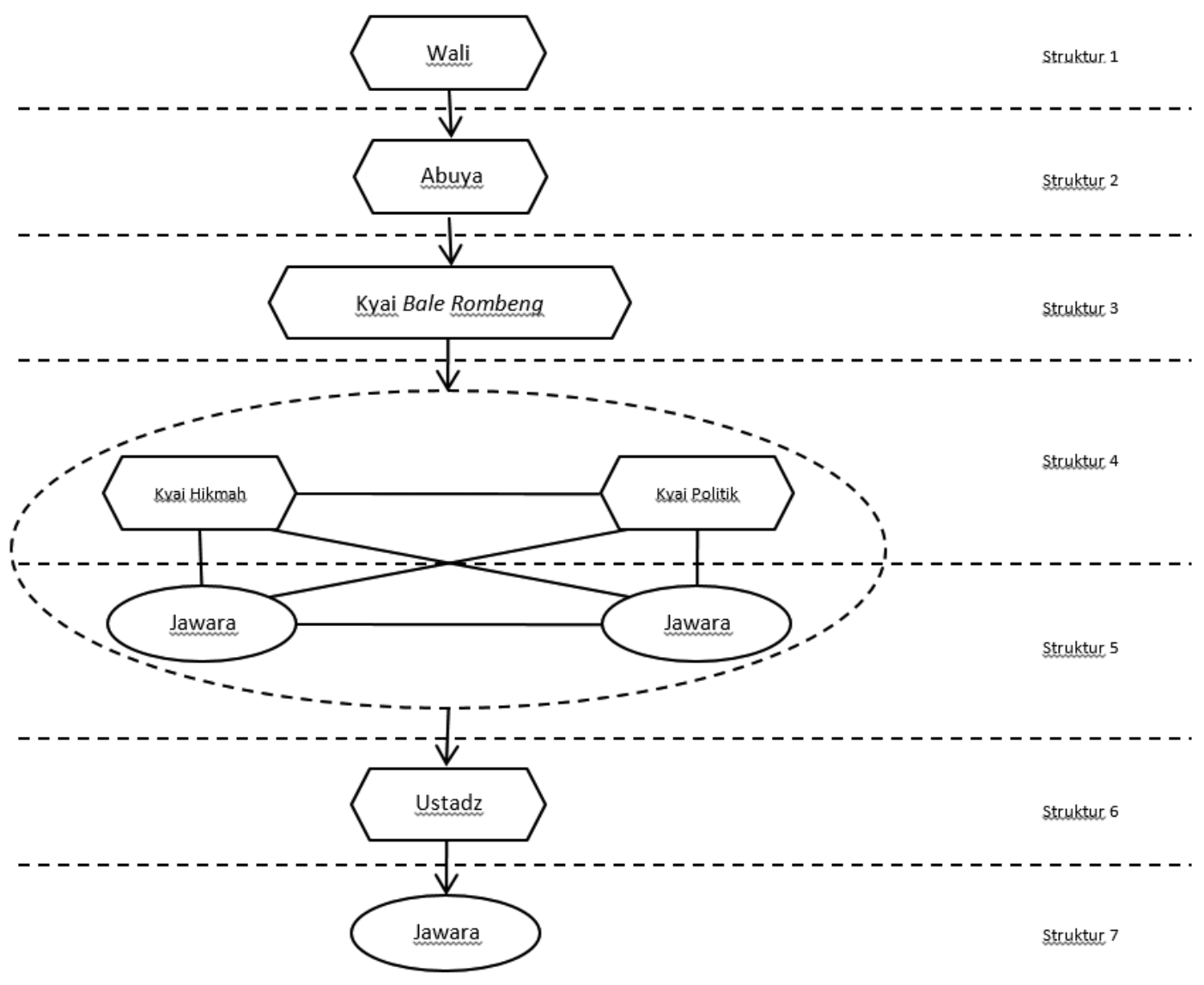

Gambar 2

Struktur Kekuasaan Ulama dan Jawara 
kondisi dimana pengaruh sosial jawara lebih besar misalnya perbandingan antara jawara kolot dengan ustadz atau juga antara jawara politik dengan ustadz, maka posisi relatif lebih tinggi jawara. Lain halnya jika diperbandingkan dengan jenis ulama lainnya yaitu kiai hikmah, kiai politik, kiai bale rombeng ataupun abuya, maka jawara berada pada posisi subordinat. Pada kondisi ini terjalin relasi patron-klien sebagai bentuk ketundukan dari seorang murid kepada gurunya. Adapun kiai hikmah, kyai politik, jawara non politik dan jawara politik digambarkan dalam satu lingkaran dengan maksud menjelaskan bahwa diantara keempat unsur tersebut terjadi hubungan pertukaran sehingga diantara unsur-unsur tersebut pada dasarnya berlangsung hubungan ketergantungan kekuasaan satu sama lain.

Hubungan ketergantungan kekuasaan tersebut adalah, misalnya, kiai hikmah membutuhkan jawara nonpolitik dalam memperkuat pengaruh sosialnya, sementara jawara kolot membutuhkan kiai hikmah dalam rangka meningkatkan kemampuan supra naturalnya. Sementara itu, kiai politik dan jawara politik berkolaborasi untuk saling memperkuat pengaruh politiknya.

\section{Periodisasi Pemerintahan dan Pergeseran Peran Ulama-Jawara}

Peran sosial-politik ulama dan jawara di Banten berkaitan erat dengan kebijakankebijakan politik yang berlangsung dalam setiap periode pemerintahan. Hal ini sangat penting karena kebijakan yang dikeluarkan oleh pemerintahan pada suatu periode sangat berpengaruh terhadap langkah dan gerakan ulama dan jawara. Bahkan, terdapat beberapa kebijakan yang secara langsung berhubungan dengan kehidupan ulama dan jawara.

Sebagai sebuah dinamika yang mengekor kepada periodisasi pemerintahan tersebut, secara jelas sangat tampak pergeseran peran ulama dan jawara yang tidak bisa dilepaskan dari output kebijakan sistem politik baik di level lokal maupun nasional. Namun secara politik, gejala yang paling tampak dalam tataran politik lokal kontemporer adalah menurunnya peran politik ulama, sementara dalam sisi lain justru menguatnya peran politik yang dimiliki oleh kaum jawara.

Kesimpulan tersebut, diantaranya dapat ditelusuri dari temuan Hidayat (Nordholt, 2007: 272) bahwa sisi persamaan antara jawara dan ulama ditunjukkan dengan masih dominannya peran jawara dan ulama sebagai kekuatan politik informal. Sementara, sisi perbedaannya diperlihatkan oleh semakin menurunnya, atau bahkan nyaris menghilangnya, peran resmi ulama dalam penyelenggaraan pemerintahan. Semakin terpinggirkannya peran ulama ini, menurut Hidayat, terjadi akibat dari kebijakan pemerintah kolonial Belanda yang menghapuskan peran resmi ulama dalam lembaga Faqih Najamudin, dan diteruskan oleh kebijakan pemerintah Republik Indonesia yang secara tegas memisahkan antara agama dan negara, secara langsung maupun tidak.

Sama halnya dengan peran yang dimainkan kaum ulama, jawara juga memberikan konfigurasi sosial politik yang khas di Banten dari masa pemerintahan kesultanan Banten hingga saat ini. Ini setidaknya dapat ditelusuri dari penelitian Hudaeri (2002). Hudaeri menjelaskan bahwa terjadi derogasi (pendegradasian nama jawara) istilah jawara sehingga saat ini kesan yang diberikan masyarakat cenderung memandang negatif kepada jawara. Meskipun demikian, kedudukan jawara dalam masyarakat Pandeglang tetap dipandang sebagai salah satu elit yang memainkan peranannya yang sangat signifikan. Diantara peran yang dimainkan oleh jawara tersebut adalah sebagai jaro (kepala desa), penjaga keamanan, guru silat dan guru ilmu magis. Adapun jaringan tradisional yang dibangun kelompok jawara mengandalkan hubungan kedekatan emosional yang dalam, sehingga jaringan yang terbentuk pun melalui hubungan kekerabatan, baik melalui hubungan nasab atau perkawinan, hubungan guru dengan murid dan lembaga sosial-keagamaan seperti pesantren dan paguron (perguruan silat).

Berdasarkan penelitian Nasution (1994: 54-71) diuraikan secara jelas sejak masa kesultanan ulama menjadi pilar penting dalam kehidupan bernegara dan bermasyarakat. Dalam kondisi inilah sultan sebagai negarawan memerankan pula tugasnya sebagai panotogomo (penata kehidupan keagamaan), satu konsep yang mempersatukan jiwa ulama dan umaro dalam satu organisasi kekuasaan pemerintah kesultanan. Tampak pula pada masa ini adalah bagaimana otoritas kharismatik, tradisional dan otoritas legalrasional bersatu padu membentuk kesatuan otoritas penuh yang terhimpun dalam konsep ulama-umaro tersebut.

Pada masa kolonialisme Belanda, istilah yang paling terkenal adalah apa yang 
diintrodusir oleh Kartodirdjo (1984: 190) sebagai "bandit". Istilah ini tentunya adalah upaya terstruktur Belanda untuk menderogasi jawara di masyarakat Banten.

Penderogasian nama jawara oleh Belanda tersebut, tentunya, sangat bertentangan dengan konsep awal jawara sebagai santri dalam terminologi yang diintrodusir Tihami (1992: 99-100), sehingga dapat dipahami pada masa ini jawara terpilah kepada dua bentuknya yaitu yang pertama adalah jawara yang memiliki jiwa patriotisme sebagai didikan kiai dan berperan besar terhadap perjuangan pergerakan kemerdekaan dan kedua adalah jawara yang bertipikal pembelot perjuangan yang berlabel "bandit", "perampok" atau "pelanggar hukum" sebagai bentukan Belanda untuk menderogasi citra patriotisme jawara yang sesungguhnya. Pelekatan citra negatif jawara ini dapat dipahami sebagai keberhasilan strategi hegemoni kolonialis.

Selain keberhasilan Belanda dalam menderogasi konsep jawara, seiring dengan dibumihanguskannya istana Kesultanan Banten, hancur pula puing-puing keulamaan Banten termasuk konsep ulama-umaronya sehingga kaum ulama terpinggirkan ke pedesaan. Ketika kaum ulama (termasuk jawara) terpinggirkan di pedesaan, maka kepemimpinan pedesaan pun beralih dari para jaro kepada kaum ulama. Untuk itulah peran politik ulama lebih banyak bermain dalam tataran pedesaan. Dari rangkaian peran politik ulama yang dijalankannya, yang terpenting adalah perannya dalam kepemimpinan gerakan-gerakan perlawanan terhadap kaum penjajah. Gerakan inilah yang digambarkan secara apik oleh Kartodirdjo (1984: 305-316) tentang keterpaduan kaum ulama, jaro, dan segenap unsur masyarakat pedesaan Banten saat itu dalam proses gerakan perlawanan tersebut melalui formula pemberontakan petani (masyarakat pedesaan).

Keterpinggiran ulama ke level pedesaan ini, meskipun dari aspek politik semakin terdegradasi, namun dalam syiar keislaman sangat diuntungkan karena masyarakat pedesaan semakin dekat hubungannya dengan para ulama, terutama kaum ulama bangsawan yang pada masa kolonialis relatif terkungkung dalam dunia pemerintahan saja. Kedekatan hubungan inilah yang memberikan peluang besar kaum ulama untuk menanamkan gerakan kesadaran perjuangan untuk menggulingkan kaum penjajah.

Pilar penting ulama sebagai umaro masih kental dalam periode awal kemerdekaan. Hal ini diindikasikan dengan diangkatnya K.H. Tubagus Ahmad Chatib sebagai residen pertama Banten dan juga Kolonel K.H. Sjam'unn sebagai pimpinan Brigade Tirtayasa (lihat dalam Suharto: 2001, Lubis: 2003). Hal yang sama sebenarnya juga terjadi untuk kabupaten-kabupaten yang ada di Banten termasuk Pandeglang dimana saat itu yang bertindak sebagai bupatinya adalah K.H. Abdul Halim. Bahkan tidak hanya bupati, jabatan-jabatan dibawahnya pun yaitu para wedana, camat dan kepala kesatuan kepolisian, didominasi oleh kaum ulama (Suharto, 2001: 125).

Menurut Suharto (2001: 125), tampilnya ulama dalam politik lokal Banten merupakan usaha yang telah lama mereka perjuangkan setelah kedudukannya dimusnahkan oleh kolonialisme Belanda. Pada kondisi lain, rakyat menghendaki tampilnya para ulama sebagai amirul mukminin, sehingga adanya kekosongan pemerintahan pada masa awal kemerdekaan merupakan kesempatan paling baik bagi kaum ulama untuk tampil kembali sebagai umaro. Adapun menurunnya kembali peranan ulama dalam politik lokal Banten, Suharto (2001: 137) menjelaskan hal ini terjadi karena upaya pemerintah yang dilakukan secara gradual dengan mengirimkan para tokoh pamong praja dari pusat selain karena banyak pula ulama yang mengundurkan diri secara pribadi karena merasa tidak memiliki kemampuan dalam urusan pemerintahan seperti yang dilakukan oleh K.H. Abdul Halim.

Masa Orde Baru adalah masa dimana ulama dan jawara "dikebiri" secara sosial maupun secara politik. Secara sosial, ulama berhadapan dengan beberapa jargon pembangunan yang memperhadapkannya dengan kepentingan-kepentingan pemerintah semisal program Keluarga Berencana (KB) dan Sumbangan Dana Sosial Berhadiah (SDSB). Pandangan banyak kalangan ulama terhadap kedua program pemerintah tersebut tentunya adalah mengharamkannya. Tindakantindakan kekerasan pun tidak luput diterima oleh kaum ulama itu, misalnya untuk kasus Banten adalah apa yang diterimakan oleh Kiai Sarmin karena sering memberikan dakwah yang melarang umat mengikuti program KB. Tidak jarang label PKI (Partai Komunis Indonesia) atau NII (Negara Islam Indonesia) dilekatkan kepada para kyai tersebut agar masyarakat menjauhinya karena pada masa itu kedua label tersebut adalah label common enemy. 
Secara politik pun kiai semakin tertekan (hegemoni negara), adanya larangan untuk menggunakan simbol-simbol agama dalam politik salah satunya, sehingga lambang ka'bah yang digunakan Partai Persatuan Pembangunan pada saat itu digantikan dengan lambang bintang. Pengerucutan dua partai (PPP dan PDI) serta satu golongan kekaryaan (Golkar) yang menjadi kebijakan politik Orde Baru juga semakin membatasi peran politik ulama. Praktis, haluan idealisme politik agamanya hanya tercurah kepada satu partai yaitu PPP. Sementara, pengaruh Golkar semakin kuat, sehingga tidak sedikit pula yang merekrut kaum ulama sebagai kader politiknya. Kaum ulama pun terpilah kepada dua kubu, yaitu PPP dan Golkar.

Diantara sekian peristiwa yang paling menggemparkan berkaitan dengan ulama dan negara adalah peristiwa ditangkap dan dipenjarakannya Abuya Dimyati menjelang Pemilu 1977. Beragam cerita mistis pun mewarnai peristiwa penangkapan Abuya Dimyati tersebut. Cerita mitos yang mengitarinya adalah berkaitan dengan keyakinan sebagian besar masyarakat Pandeglang bahwa meskipun Abuya Dimyati berada dipenjara, namun disaat yang bersamaan ia terlihat berada di pesantrennya di Cidahu atau ada juga yang menjumpainya di Banten dan lain sebagainya. Selain itu, aparat yang melakukan penangkapan terhadapnya diceritakan mendapatkan musibah seperti hakim yang memvonisnya menjadi bisu dan aparat polisi yang melakukan penangkapnya menjadi gila (data hasil wawancara, lihat pula dalam Hamid (2011: 348).

Menurut Hamid (2011: 347), kiai yang tidak mendukung Golkar, dalam istilahnya adalah kiai non kooperatif akhirnya menghindari dunia politik dan memfokuskan diri pada aktivitas mengajar. Diantaranya ada pula yang memilih hijrah seperti yang dilakukan Kiai Damanhuri (ulama dari Cihideung Pandeglang) yang migrasi ke Kota Mekah.

Menurut informan tokoh ulama (Haji Maman Badarzaman), trik-trik politik Golkar pada saat itu tidak bisa ditandingi selain karena menjadi pihak penguasa, soliditas diantara para kadernya pun terbina dengan baik dibandingkan dengan dua partai lainnya baik PPP maupun PDI. Selain itu, sayapsayap politik Golkar menyentuh kepada akar rumput yang paling dalam melalui kekuatan birokrasi yang meresap sampai di pedesaan. Haji Maman Badarzaman menambahkan bahwa kekuatan Golkar semakin tidak tertandingi dan semakin melemahkan kaum ulama terlebih setelah organisasi-organisasi keislaman menginternalisasikan diri kepada kelembagaan Golkar.

Sebagaimana halnya dengan kaum ulama, kelompok jawara seolah memiliki golok rompang (ompong), tumpul dan tidak berguna. Menurut Haji Maman Badarzaman, pada akhirnya jawara seolah nyalindung dina gelung, maksudnya adalah berlindung dengan hidup memanfaatkan orang lain, dengan cara memanfaatkan fasilitas-fasilitas yang diberikan oleh pihak pemerintah (Golkar). Baik kaum ulama yang terkurung dalam kerangkeng Satkar Ulama, begitu pula halnya dengan jawara yang terjebak dalam Satkar Jawara yang menjadikan keduanya seolah berada dalam ketiak kekuasaan Golkar yang pada prinsipnya adalah hegemoni negara pula. Untuk para kiai politik, terutama yang sangat pragmatis, sebenarnya kondisi ini dapat dikatakan sebagai berkah karena peluang menduduki jabatan-jabatan politik sangat besar. Selain melalui kelembagaan Golkar, ulama juga "diberikan jatah" oleh pemerintah melalui jalur lain yaitu Fraksi Utusan Golongan dan tidak sedikit kaum ulama yang "diselipkan" oleh Golkar dalam fraksi tersebut.

Hal yang paling tampak dalam realitas kekinian (pasca era otonomi daerah) peranan ulama dan jawara dalam politik lokal Banten sebagaimana digambarkan oleh Hamid (2010) adalah terjadinya pergeseran peran kiai dari cultural broker menjadi political broker; sementara itu, peran politik jawara semakin menguat yang sebagian besar "difasilitasi" oleh dinamika sistem politik yang menguntungkan kedudukannya terutama diawali oleh masa Orde Baru, yang dominasinya jauh mengangkangi kemampuan ulama. Dalam analisis Faridl (2003: 200-201), keterpinggiran kaum ulama ini karena gagap atau tidak siap terhadap perubahan sistem politik yang terlalu cepat dari lahirnya era reformasi.

\section{Dinamika Peran Sosial Politik Ulama dan Jawara}

Berdasarkan pengamatan peneliti, pada masa lalu sekitar 1980-an, jawara yang memberikan pelajaran mengaji (jawara sebagai guru ngaji) sangatlah diminati oleh, terutama, kaum muda karena selain mendapatkan bekal ilmu agama juga mendapatkan kemampuan bela diri. Setiap 
malam Jum'at kaum muda dan tua bersamasama melakukan keceran, peureuhan, dan ulinan yaitu beberapa rangkaian tradisi kajawaraan dan kegiatan pelatihan bela diri lainnya, kemudian di malam Minggunya biasa dilakukan khusus untuk kegiatan ulinan (permainan jurus).

Saat ini, tidak banyak guru ngaji yang juga memberikan pelajaran bela diri, sehingga tradisi lokal ini dari waktu ke waktu semakin tergerus modernisasi. Dalam bagian lain, kondisi ini berpengaruh pula terhadap peran dan kedudukan jawara di masyarakat. Kondisi yang sama juga tidak jauh berbeda dengan peran yang dimainkan kaum ulama. Ini adalah gambaran kecil dari pergeseran yang terjadi karena proses kontestasi dengan proses modernisasi.

Pergeseran peran sosial-politik ulama dan jawara juga erat kaitannya dengan dinamika pelaku penguasa yang terjadi dari setiap periodenya sehingga terdapat semacam suksesi kepemimpinan politik diantara setiap periode pemerintahan. Oleh karenanya, rezim penguasa memberikan pengaruh besar terhadap peran ulama dan jawara, baik itu rezim yang memberikan peluang maupun meminggirkan peranannya.

Berdasarkan Tabel 1 dapat dijelaskan bahwa berdasarkan periodisasi pemerintahan, terutama dari aspek politik terjadi peningkatan peran yang dilakukan oleh kelompok jawara, sementara dalam kondisi lain peran ulama mengalami penurunan. Kondisi inilah yang dijelaskan di awal tulisan ini sebagai bentuk dominasi kaum jawara dalam politik lokal, meskipun dalam aspek sosial pengaruh ulama masih cukup kuat.

Pada Gambar 2 yang memuat struktur kekuasaan ulama dan jawara sebenarnya juga menggambarkan dominasi ulama tersebut. Konseptualisasi ulama dan jawara dalam masyarakat Pandeglang berkontribusi besar terhadap struktur kekuasaan dan dominasi ulama tersebut.

Terdapat beberapa nilai sosial yang memengaruhi adanya dominasi ulama tersebut yaitu: pada prinsipnya jawara adalah murid kiai, keyakinan akan barokah yang diberikan kiai, keyakinan bahwa elmu putih lebih unggul daripada elmu hideung, dan pada banyak kondisi jawara meminta bantuan dari ulama baik untuk meningkatkan pengaruh sosial maupun politiknya. Kondisi tersebut menempatkan jawara berada pada posisi subordinat terhadap ulama sehingga hubungan yang terjadi pun adalah relasi patron-klien. Namun demikian, sebagaimana telah disinggung sebelumnya, terdapat karakter pembeda antara relasi kekuasaan patron-klien Scott dengan kekhasan relasi kekuasaan patron-klien ulama dan jawara yang dalam hal ini peneliti sebut sebagai relasi master-servant.

Dasar relasi pada model relasi patronklien relasi terjadi karena pihak patron memberikan bantuan kepada klien-nya yang dalam kondisi sangat terbatas secara ekonomi. Oleh karenanya hubungan antara patron sangat langgeng karena patron selalu dapat menutupi kebutuhan hidup klien yang sangat terbatas. Ketergantungan inilah yang menjalin hubungan keduanya berikatan secara kuat. Sementara itu, dalam relasi master-servant, relasi terjadi karena takluk dan tunduknya pihak servant terhadap kelebihan kemampuan yang dimiliki oleh master.

Berkaitan dengan dasar relasinya, maka sumber relasi yang membangun hubungan dalam relasi patron-klien, tentunya adalah sumber daya ekonomi dimana master dapat "mengelola" kepatuhan klien melalui kelebihan sumber daya ekonomi tersebut. Hal ini berbeda dengan relasi master-servant dimana sumber relasinya berdasarkan kepada pengetahuan agama (supranatural) dalam hal ini servant terikat kepada kepentingan pengetahuan agama atau supranatural tersebut.

Dasar pertukaran dalam relasi patronklien adalah sesuatu yang konkret, yaitu patron memberikan bantuan berbentuk uang atau barang dan klien membalasnya dengan hal yang sama meskipun kadangkala berbentuk jasa. Sementara dalam relasi master-servant, dasar pertukaran relatif samar, yaitu dimana servant akan memberikan segala daya upayanya secara ikhlas untuk suatu harapan master secara ikhlas pula memberikan pengetahuan dan kemampuannya kepada servant.

Berdasarkan kemanfaatan atau kepentingan pertukarannya, relasi patron berlangsung karena klien membutuhkan patron dalam perlindungan kehidupannya, sementara patron membutuhkan klien untuk mendukung kehidupannya. Sementara itu dalam relasi master-servant, relasi yang terjadi berkaitan dengan harapan dan keberkahan dimana servant mensuplai kebutuhan master dengan satu harapan master memberikan keberkahannya. Keberkahan tersebut kadangkala hanyalah 
Tabel 1

Dinamika Peran Sosial Politik Ulama dan Jawara

\begin{tabular}{|c|c|c|c|}
\hline \multirow{2}{*}{ No. } & \multirow{2}{*}{$\begin{array}{c}\text { Periodisasi } \\
\text { Pemerintahan }\end{array}$} & \multicolumn{2}{|c|}{ Peran Sosial-Politik } \\
\hline & & Ulama & Jawara \\
\hline 1. & $\begin{array}{l}\text { Kesultanan } \\
\text { Banten }\end{array}$ & $\begin{array}{l}\text { - Pejabat pemerintahan } \\
\text { - Penasehat agama (kadi) } \\
\text { - Pelaksana syiar/dakwah }\end{array}$ & - Pengawal para ulama \\
\hline 2. & $\begin{array}{l}\text { Kolonialisme } \\
\text { Belanda }\end{array}$ & $\begin{array}{l}\text { - Aktor utama gerakan perlawanan } \\
\text { - Suksesor kepemimpinan elit desa } \\
\text { - Pelaksana syiar/dakwah }\end{array}$ & $\begin{array}{l}\text { - Pengawal gerakan perlawanan } \\
\text { - Pejabat pemerintahan desa } \\
\text { (sebagai jaro) } \\
\text { - Bandit sosial }\end{array}$ \\
\hline 3. & $\begin{array}{l}\text { Awal } \\
\text { Kemerdekaan }\end{array}$ & $\begin{array}{l}\text { - Pejabat pemerintahan } \\
\text { - Pejabat militer } \\
\text { - Perekat (u n sur pe mersatu) } \\
\text { negara kesatuan RI } \\
\text { - Pimpinan pejuang pembela kemerdekaan } \\
\text { - Pelaksana syiar/dakwah } \\
\text { - Guru supra natural }\end{array}$ & $\begin{array}{l}\text { - Guru ngaji } \\
\text { - Guru silat } \\
\text { - Ahli pengobatan tradisional } \\
\text { - Laskar pejuang pembela } \\
\text { kemerdekaan }\end{array}$ \\
\hline 4. & Orde Baru & $\begin{array}{l}\text { - Vote getter politik pemerintah } \\
\text { - Pelaksana syiar/dakwah }\end{array}$ & $\begin{array}{l}\text { - Guru ngaji } \\
\text { - Guru silat } \\
\text { - Ahli pengobatan tradisional } \\
\text { - Vote getter politik pemerintah }\end{array}$ \\
\hline 5. & $\begin{array}{l}\text { Era Otonomi } \\
\text { Daerah }\end{array}$ & $\begin{array}{l}\text { - Vote getter partai politik } \\
\text { - Pelaksana syiar/dakwah }\end{array}$ & $\begin{array}{l}\text { - Guru silat } \\
\text { - Ahli pengobatan tradisional } \\
\text { - Vote getter partai politik } \\
\text { - Political broker } \\
\text { - Economic broker } \\
\text { - Pejabat politik }\end{array}$ \\
\hline
\end{tabular}

Sumber: Kartodirdjo (1984), Tihami (1992), Nasution (1994), Suharto (2001), Hamid (2010) dan pengamatan penelitian yang diolah peneliti.

sebatas do'a tidaklah berbentuk pemberian pengetahuan keilmuan agama, jadi sangatlah immateril.

Dalam relasi patron-klien, patronlah yang sebenarnya lebih aktif melakukan pemeliharaan relasi dimana klien bergantung kepada relasi tersebut. Sementara, dalam relasi master-servant, yang melakukan pemeliharaan relasi adalah dari pihak servant, sementara master bertindak memilih servant sesuai seleranya untuk diberikan keberkahan. Jadi, kalau dalam relasi patron-klien yang aktif adalah pihak patron, sementara dalam relasi master-servant yang justeru aktif adalah pihak servant-nya.

Dalam proses pembentukan relasinya dalam relasi patron-klien, pada mulanya pihak patronlah yang mendatangi klien dengan menawarkan sejumlah bantuan atau kadangkala klien mendatangi patron karena tertekan kebutuhan. Kondisi ini berbeda dengan proses yang terjadi dalam relasi master-servant dimana servant-lah yang selalu memiliki inisiatif mendatangi master dan mengajukan diri menjadi servant, sehingga master sifatnya sangat pasif. Pasifnya master karena ia merasa tidak terlalu bergantung kepada relasi tersebut.

Jika dilihat dari ciri-ciri di atas, berdasarkan pendekatan keseimbangan kekuasaannya tampak bahwa baik klien maupun servant berada pada posisi subordinat, namun keduanya berbeda dalam tipikal ketergantungannya dimana jika klien melepaskan diri dari relasi tersebut maka kehidupannya akan terancam. Sementara, servant tidak demikian dimana ia dapat saja melepaskan diri dari relasinya dengan master dan tidak ada risiko yang ditanggungnya akibat dari pemutusan relasinya dengan master. Meskipun demikian, kedalaman relasi secara personal justru terjadi dalam relasi masterservant, misalnya dalam kasus hubungan kiai dan santri maka santri bersedia secara ikhlas membawakan sandal, menyediakan air untuk mandi, menyediakan makan dan pelayananpelayanan yang sifatnya sangat personal.

Dalam kondisi ini tampak jelas santri terhegemoni secara mendalam (fisik), dimana tidak ada perasaan keberatan dari santri untuk melakukan pelayanan kepada kyai, bahkan ia akan sangat senang jika terpilih oleh kiai untuk menjadi pelayannya. Tindakan santri tersebut sama dengan apa yang dilakukan 
Tabel 2

Perbedaan Antara Relasi Patron-Klien dan Relasi Master-Servant

\begin{tabular}{|l|l|l|}
\hline \multirow{2}{*}{ Aspek Pembeda } & \multicolumn{2}{c|}{ Jenis Relasi } \\
\cline { 2 - 3 } & \multicolumn{1}{|c|}{ Patron-Client Relation } & \multicolumn{1}{c|}{ Master-Servant Relation } \\
\hline Dasar relasi & $\begin{array}{l}\text { Pemberian bantuan dan keterbatasan } \\
\text { hidup }\end{array}$ & Penaklukan dan ketundukan \\
\hline Sumber relasi & Sumber daya ekonomi & Pengetahuan agama \\
\hline Dasar pertukaran & Pertukaran materi & pertukaran immateri (keikhlasan) \\
\hline $\begin{array}{l}\text { Signifikansi } \\
\text { pertukaran }\end{array}$ & $\begin{array}{l}\text { Perlindungan dari patron, dukungan } \\
\text { dari client }\end{array}$ & $\begin{array}{l}\text { Berkah dari master (kyai), harapan } \\
\text { dari servant (santri/jawara) }\end{array}$ \\
\hline $\begin{array}{l}\text { Ketergantungan pada } \\
\text { relasi }\end{array}$ & $\begin{array}{l}\text { Patron yang memelihara relasi dan } \\
\text { client bergantung pada relasi tersebut }\end{array}$ & $\begin{array}{l}\text { Master memilih servant, servant } \\
\text { memelihara relasi agar bisa terpilih }\end{array}$ \\
\hline $\begin{array}{l}\text { Proses pembentukan } \\
\text { relasi }\end{array}$ & $\begin{array}{l}\text { Patron yang mendatangi client dan } \\
\text { menawarkan sejumlah bantuan, } \\
\text { meskipun kadangkala client jugan } \\
\text { mendatangi patron karena tekanan } \\
\text { kehidupan }\end{array}$ & $\begin{array}{l}\text { Servant yang mendatangi master } \\
\text { servant-nya. }\end{array}$ \\
\hline
\end{tabular}

Sumber: Analisis peneliti

oleh jawara ketika dengan sungguh-sungguh ia melakukan apapun demi harapan berkah yang diberikan oleh kiai.

Berdasarkan uraian di atas, dapat dijelaskan bahwa peran sosial-politik ulama dengan kondisi terakhir yang menunjukkan dominasi jawara dalam arena politik dan dominasi ulama dalam aspek sosialnya sangat dipengaruhi oleh nilai-nilai sosial masyarakat Pandeglang yang membentuk suatu karakter relasi patron-klien yang khas yaitu relasi master-servant.

\section{Simpulan dan Saran}

Terdapat dua faktor utama yang memengaruhi dinamika peran sosial politik ulama dan jawara yaitu kebijakan politik yang dilakukan oleh pemerintah pusat dan aspek sosial-budaya yang melingkarinya. Artinya, terdapat beberapa kebijakan yang langsung atau tidak langsung ditujukan untuk memersempit atau memerluas gerakan ulama dan jawara. Misalnya, kebijakan yang dilakukan kolonialis Belanda dengan mempolitisasi jawara sebagai bandit sosial jelas merupakan langkah pelabelan negatif kaum jawara yang pada akhirnya menurunkan derajat sosialnya. Begitu pula halnya dengan yang terjadi pada masa Orde Baru dimana pembentukan satkar ulama dan jawara tidak lebih dari upaya dari pemerintah untuk mengontrol aktivitasnya (menghegemoni ulama dan jawara). Sementara itu, menyangkut nilai sosial-budaya terutama karakter agraris, tradisional dan religius dari masyarakat Pandeglang relatif tidak mengalami perubahan meskipun proses modernisasi lambat laun memengaruhinya. Kondisi ini menempatkan penghargaan ulama dan jawara memiliki status dan kedudukan yang tinggi, terutama untuk masyarakat pedesaan.

Adanya dinamika peranan sosial politik ulama dan jawara yang berjalan berkesesuaian dengan perubahan dalam periodisasi pemerintahan yang mengindikasikan bahwa faktor kebijakan politik memberikan pengaruh yang sangat signifikan terhadap peran sosial politik ulama dan jawara; dan ini mengindikasikan juga bahwa terdapat kepentingan politik (political interest) dari negara untuk "mengarahkan" (menghegemoni) peran sosial politik ulama dan jawara. Konteks yang paling nyata adalah ketika kebijakan politik yang dilakukan pada masa Orde Baru dengan membuat satkar ulama dan jawara sebagai pilar politik penyokong Golkar saat itu.

Kekuasaan sosial ulama lebih dominan dibandingkan dengan jawara, meskipun dalam politik praktis di tingkat lokal jawara jauh lebih mendominasinya. Hal ini menyebabkan bahwa dalam konteks pengaruh yang lebih luas dan mendalam terhadap sistem sosial-politik, maka ulama tetap lebih superior dibandingkan dengan jawara. Di sisi lain, relasi masterservant yang terbentuk antara ulama dan jawara di Pandeglang semakin menempatkan posisi subordinat jawarat terhadap ulama. Kondisi ini pada prinsipnya merupakan gambaran bahwa peran sosial-politik ulama di Pandeglang lebih besar dibandingkan dengan 
peran sosial-politik jawara.

Sebagai sebuah konstruksi sosial, peran sosial-politik ulama dan jawara saat ini merupakan realitas sosial yang sudah teruji kematangannya dalam membentuk tatanan sosial masyarakat Pandeglang. Kenyataan adanya dominasi jawara dalam arena politik praktis di Pandeglang sejatinya dimaknai sebagai sebuah proses sosial normal dalam menuju tatanan sosial yang khas Pandeglang. Adanya wacana politik dinasti dalam konteks dominasi jawara di Banten umumnya dan Pandeglang khususnya sejatinya dimaknai sebagai sebuah proses sosial yang normal pula. Dalam hal ini dimaknai sebagai sebuah pencarian jati diri demokrasi lokal di Pandeglang. Namun hal ini dapat menjadi persoalan sosial ketika dominasi politik jawara membawa dampak buruk terhadap konstelasi sosial politik Pandeglang misalnya adanya korupsi birokrasi, pelayanan publik yang buruk dan marginalisasi pihak-pihak tertentu sebagaimana yang terjadi pada kasus korupsi mantan Gubernur Banten, Ratu Atut Chosiyah. Dalam kondisi ini, diperlukan kekuatan negara untuk mereduksi dampak buruk tersebut. Oleh karenanya, meskipun dominasi jawara di Pandeglang sebagai sebuah realitas sosial, kelembagaan negara sangat dibutuhkan untuk mengendalikan dominasi yang menjurus kepada kekuasaan absolut. Hal ini perlu dilakukan, karena kekuasaan absolut relatif mendorong terjadinya perilaku KKN (Korupsi, Kolusi dan Nepotisme).

Kekuatan negara untuk menekan perilaku KKN ini dapat diwujudkan melalui perangkat regulasi yang membatasi peluang seseorang untuk melakukan penyalahgunaan wewenang politiknya. Contoh konkretnya adalah fungsi pejabat pembina kepegawaian di tingkat lokal bagi kepala daerah seyogianya perlu ditinjau ulang karena sering dijadikan alat untuk mengarahkan birokrasi kepada kepentingan politik kepala daerah. Kelembagaan negara sangat urgen karena sebagaimana dijelaskan sebelumnya peran sosial-politik ulama dan jawara sangat dipengaruhi oleh kebijakan politik. Hal ini berarti salah satu pengendali terjadinya prilaku KKN sebagai akibat dominasi politik jawara adalah melalui pengetatan dalam kebijakan politik.

\section{Daftar Pustaka}

Bandiyah. (2010). Evolusi Jawara di Banten (Studi Evolusi dari Bandit Menjadi Pejabat).
Jurnal Interaktif Universitas Brawijaya. Vol. 1, No.2, pp. 111-171.

Bungin, B. (ed.), (2010). Analisa Data Penelitian Kualitatif. Jakarta: PT. RajaGrafindo Persada.

Faridl, M. (2003). Peran Sosial Politik Kiai di Indonesia. Jurnal Mimbar. Vol. 19, No. 2, pp. 195-202.

Faridl, M. (2005). Perilaku Sosial Politik Kiai di Tengah Masyarakat Transisi Kasus di Wilayah Cirebon dan Bandung. Jurnal Mimbar. Vol. 21, No. 2, pp. 165-177.

Hamid, A. (2010). Memetakan Aktor Politik Lokal Banten Pasca Orde Baru: Studi Kasus Kiai dan Jawara di Banten. Jurnal Politika. Vol. 1, No. 2, pp. 32-45.

Hamid, A. (2011). Pergeseran Peran Kyai dalam Politik di Banten Era Orde Baru dan Reformasi. Al Qalam. Vol. 28, No. 2, pp. 339-364.

Hudaeri, M. (2002). Jawara di Banten: Peran, Kedudukan dan Jaringannya (Laporan Penelitian). Serang: STAIN SMHB.

Jessop B. (2006). Developments in Marxist Theory in Nash $\mathrm{K}$ dan Scott A (ed.). The Blackwell Companion to Political Sociology. Malden(US): Blackwell Publishing, pp. 7-16.

Karomani. (2005). Ulama dan Jawara: Studi tentang Persepsi Ulama terhadap Jawara di Menes Banten Selatan. Jurnal Mediator. Vol. 6, No. 2, pp. 228-235.

Kartodirdjo S. (1984). Pemberontakan Petani Banten 1888. Jakarta: Pustaka Jaya.

Lubis, N.H. (2003). Banten dalam Pergumulan Sejarah: Sultan, Ulama, Jawara. Pustaka. Jakarta: LP3ES.

Hidayat S. (2007). Bisnis dan Politik di Provinsi Banten, dalam Nordholt, N.S (ed.). Politik Lokal di Indonesia. Jakarta: KITLV JakartaYayasan Obor Indonesia, pp. 268-274.

Pribadi, Y. (2011). Strongmen and Religious Leaders in Java: Their Dynamic Relationship in Search of Power. Jurnal Al-Jamiah. Vol. 49, No. 1, pp. 159-190.

Scott JC. (1992). Perlawanan Kaum Tani. Jakarta: Yayasan Obor.

Scott JC. (1994). Moral Ekonomi Petani: Pergolakan dan Subsistensi di Asia Tenggara. Jakarta: LP3ES.

Suhaedi (2003). Tasbih dan Golok: Studi tentang Kharisma Kyai dan Jawara di Banten. Jurnal Istiqro. Vol. 2, No. 1, pp. 57-87.

Suharto. (2001). Banten Masa Revolusi, 1451949: Proses Integrasi Dalam Negara Kesatuan Republik Indonesia (Disertasi). Depok: UI.

Tihami, M.A. (1992). Kiyai dan Jawara di Banten: Studi tentang Agama, Magi dan Kepemimpinan di Desa Pasanggrahan Serang (Tesis). Depok: UI.

Yin, R.K. (1996). Studi Kasus (Desain dan Metode). Jakarta: Rajawali Press. 